\title{
Using Interactive Web-Based Learning Multimedia to Assess Competency Standards for Installing LAN Among Vocational High School Students in Padang, Indonesia
}

\author{
Karmila Suryani $^{1 *}$, Khairudin ${ }^{2}$, Rini Widyastuti ${ }^{3}$, Riska Amelia ${ }^{4}$, S.M. Lulinda Riska ${ }^{5}$ \\ ${ }^{I}$ Faculty of Teacher Training and Education, BungHatta University \\ ${ }^{2}$ Faculty of Teacher Training and Education, BungHatta University \\ ${ }^{3}$ Faculty of Teacher Training and Education, Bung Hatta University \\ ${ }^{4}$ Faculty of Teacher Training and Education, Bung Hatta University \\ ${ }^{5}$ Padang State University \\ *Corresponding author E-mail:karmilasuryani.ptik@gmail.com
}

\begin{abstract}
This research is aimed at creating an interactive, valid, practical and effective Webרר-Based Learning Multimedia for assisting the students to learn the school subject: Installation of Local Area Network (LAN), and to meet the competency standard in such subject. To create the learning multimedia the researchers adopted Cooper's Stage-Gate Method by applying product development phases, namely: Vision, Conception, Design, Prototype, and Production. After the design process had been completed, the multimedia was validated by a team of multimedia experts, and reached a score of $94.96 \%$ which is categorized as Highly Valid. For practicality analysis, the Researcher distributed questionnaires to relevant parties so as to know the level of students interest, the process of using, the increase of active learners, the sufficiency of time, and for evaluation purposes, and it resulted in a score of $87 \%$ which is categorized as Practical. Such validity and practicality analysis were done at the Phase of Prototype. Finally, the Researchers shared the Application to all students of Computer and Network Engineering Department in Padang, Indonesia, and the results were fairly encouraging in which the learning outcomes of the students can reach the figure of $87 \%$, and the grades achieved by the students were Above Minimum Passing Criteria. In view of such results, it can be concluded that this learning multimedia has met the requirement for a mass application.
\end{abstract}

Keywords: Interactive Multimedia, LAN, Vocational High School.

\section{Introduction}

Elucidation of Law of the Republic of Indonesia number 20 of 2003 , Article 15, prescribes that vocational education is a secondary education that prepares students to primarily work in particular fields. One of such fields is Information and Communication Technology (ICT) whereby students should learn various competency-based learning strategies related to the application of the competency standards in occupational and industrial world. To achieve the results of learning which shall meet the competency of graduates, it is necessary to meet the standard process of learning. Regulation of the Minister of Education and Culture of the Republic of Indonesia number 22 sets out that Standard Process is a criteria related to the implementation of learning process in an educational unit to achieve the Graduate Competency Standards.

There are three Principles in a Learning Process, namely: (1) the learning that takes place at home, at school, and in the community, (2) the learning that implements the principle that anyone is a teacher, anybody is a learner, and anywhere is a class, and (3) the utilization of information and communication technology to improve the efficiency and effectiveness of learning. To accommodate the three principles, it is very important to develop the learning strategy and the multimedia that can be accessed easily and which can stimulate the students to learn independently, either at home, at school and in the community, and at the same time they can treat themselves as the teacher and the learner anywhere and anytime by applying the information and communication technology. This is the essence of this Research.

In view of the rapid growth of the internet where almost all students spend their time browsing and using social networking sites like Facebook, Instagram, Twitter and Whatsapp thus significantly reduce their study time, it is necessary to create a learning innovation which also makes use of Internet as teaching platform and having performance which as as interesting as social media, and as easy as accessing the social networking sites.

Based on observations at several Vocational High Schools (SMK) in Padang, Indonesia, almost all students of Computer and Network Engineering class found it difficult to reach the competency standard in the Installation of Local Network Devices (LAN) subject. Some of the problems that make students to be less interested in and face difficulties to understand the lesson is the course materials which are perceived to be rather boring, delivered only by using simple multimedia presentation like Powerpoint with simple display and whiteboard, and limited sources ofknowledge since they only depend on the explanation of the teacher in the classroom. For example, in the Installation of LAN Devices subject, sub-competence of Principles of Subnetting Process, the fixing of IP Address is still done manually, particularly in the counting process using paper and pen. Such processes are quite troublesome and prone to error when building a network, especially when preparing a big scale network. This affects the learning achievement 
of the students by an average of $63.33 \%$; which is below the Minimum Passing Criteria (MPC).To improve the effectiveness and efficiency of learning and the competence of the students in performing LAN installation, the researchers designed anInteractive Web-Based Learning Multimedia For Vocational High School Students to meet the competency standard in LAN Installation, especially for those majoring in Computer Engineering.

\section{Literature Review}

To show your reader that you have read, and have a good grasp of, the main published work concerning a particular topic or question in your field. This work may be in any format, including online sources. In the latter cases in particular, the review will be guided by your research objective or by the issue or thesis you are arguing and will provide the framework for your further work.

\section{Methods}

\subsection{Types of Research}

This is an action research that adopts andmodifies the stage gate method developed by Cooper (2005). There are 5 phases to design the Interactive Web-Based Learning Multimedia For Vocationa High School Students. (See Annexure-A)

R. G. Cooper in his book entitled "Stage-Gate ${ }^{\circledR}$ New Product Development System : A Game Plan from Idea to Launch", pages 1 to 12 elaborates five phases to be taken in creating a new product. Since the product to be created in this research would be an application, the Researches applied the five phases as follows:

\subsubsection{Phase I - Vision (Project Plan)}

The multimedia to be produced shall contain video tutorials in MP3 type on installation of LAN network, including test and evaluation part in the form of objective questions which shall popup in random. The materials will be presented in.pdf, .pp and .doc formats with animation and pictures and combined with clear, concise and bold text so that the students will find the materials interesting, easy to read and easy to absorb. In addition, interesting background will also be used with blue shade so as to minimize boredom and tiring eyes when using the learning multimedia.

\subsubsection{Phase II - Conception (Project Plan Update)}

The software used in developing this interactive learning multimedia are PHP and MySQL. Corel Draw and Photoshop applications are also used for the background design of the front page of the multimedia. The computer used for developing this interactive multimedia has the following specification: Core i5 processor, 4GB RAM, and 1TB HDD.

\subsubsection{Phase III - Design}

Designing the interface and components of the interactive webbased multimedia is part of the design process. Initially the design is done on (1) Main page (view), (2) pages of Competency Standard and Basic Competence, (3) Pages containing learning material (Videos and Documents), (4) evaluation pages and (5) instruction pages.

\subsubsection{Phase IV - Prototype}

At this phase there are several stages to be passed, namely

\section{a. Validation of product design}

There are several aspects of assessment to validate the product design, among others: (1) substance of material, (2) visual communication display, (3) learning design, and (4) software utiliza- tion. Validation is conducted by multimedia experts whose respective expertise and experience cover the contents of the product, namely the expert in multimedia contents, the expert in teaching of multimedia, and the expert in language and writing of multimedia. The three experts are lecturers of Bung Hatta University in the Faculty of InformaticsEngineering and Computer Education.

\section{b. Testing of the Product}

Prior to mass product distribution, small-scale product testing was launched to some students of Class XI, Department of Computer Engineering and Network at five Vocational High Schools in Padang City, Indonesia.

\subsubsection{Phase V - Production}

The interactive learning multimedia which has been completely produced was then hosted and uploaded so as to make it online and ready to be used anywhere by students. The interactive learning multimedia may be used as a supplement of study for the students and as an alternative material for extra-curricular learning.

\section{Research Instruments}

The instruments for the research comprise of validity sheet, practicality sheet and Multimedia Quiz Sheet. Altogether, there were 30 students participated in the research.

\subsection{Validity Sheet}

To measure the validity of this learning multimedia, the Researchers made slight adjustment so as to comply with the assessment indicatorsas set out by the Ministry of Higher Education of Indonesia (2008) as seen in the following Table 1.

\begin{tabular}{|c|c|c|}
\hline No & $\begin{array}{c}\text { Variables of } \\
\text { Validity }\end{array}$ & Indicators \\
\hline \multirow[t]{4}{*}{1} & \multirow{4}{*}{$\begin{array}{l}\text { Substances of Learning Mate- } \\
\text { rials for Installation of LAN }\end{array}$} & 1. Authenticity \\
\hline & & 2. Scope of the material \\
\hline & & 3. Up-to-date \\
\hline & & 4. Legibility \\
\hline \multirow[t]{6}{*}{2} & \multirow{6}{*}{$\begin{array}{l}\text { Visual Communication Dis- } \\
\text { play }\end{array}$} & 1. Navigation \\
\hline & & 2. Fonts \\
\hline & & $\begin{array}{l}\text { 3. Multimedia (video, sound, } \\
\text { image, and animation) }\end{array}$ \\
\hline & & 4. $\quad$ Colour \\
\hline & & 5. Animation \\
\hline & & 6. Layout \\
\hline \multirow[t]{8}{*}{3} & \multirow[t]{8}{*}{ Design } & 1. Title \\
\hline & & $\begin{array}{l}\text { 2. Competency Standard - Basic } \\
\text { Competence }\end{array}$ \\
\hline & & 3. Learning objectives \\
\hline & & 4. Materials \\
\hline & & 5. Sample of questions \\
\hline & & 6. Exercise / Simulation \\
\hline & & 7. $\quad$ Compiler \\
\hline & & 8. Reference \\
\hline \multirow[t]{3}{*}{4} & \multirow[t]{3}{*}{ Utilization of Software } & $\begin{array}{lll}1 . & \begin{array}{l}\text { Interactivity (feedback from } \\
\text { system to user) }\end{array} \\
\end{array}$ \\
\hline & & 2. Supporting Software \\
\hline & & 3. Originality \\
\hline
\end{tabular}

Source: Sungkono (2008) 


\subsection{Practicality Sheet}

Collection of data by using practicality sheet or questionnaire is useful for finding information regarding student responses and compatibility between the students and the application. Outlines of the practicality sheet as set out bythe Ministry of Higher Education(2017) shall be as shown in table 2 .

Table 2. Outline of Practicality Sheet of Learning Multimedia

\begin{tabular}{|c|c|c|}
\hline No. & $\begin{array}{l}\text { Variables of Prac- } \\
\text { ticality }\end{array}$ & Indicators \\
\hline 1. & Students Interest & $\begin{array}{l}\text { 1) Desire of the students to participate in } \\
\text { the learning. } \\
\text { 2) Interest of the students to use the inter- } \\
\text { active web-based learning multimedia. } \\
\text { 3) Interest of the students to learn with } \\
\text { designed multimedia. } \\
\text { 4) Interest of the students in the image / } \\
\text { animation of the multimedia. } \\
\text { 5) Boredom in learning the multimedia }\end{array}$ \\
\hline 2. & Process of Using & $\begin{array}{l}\text { 1) Students are easy to absorb and under- } \\
\text { stand the concept presented in the learn- } \\
\text { ing material } \\
\text { 2) Students are easy to use the designed } \\
\text { multimedia. } \\
\text { 3) By using the multimedia learning the } \\
\text { students find it easier to absorb the } \\
\text { learning concept. } \\
\text { 4) Students are easy to correlate the con- } \\
\text { cepts being learned with the real context } \\
\text { in everyday life. }\end{array}$ \\
\hline 3. & $\begin{array}{l}\text { Increase of active } \\
\text { learners }\end{array}$ & $\begin{array}{l}\text { 1) Improvement in student learning activi- } \\
\text { ties. } \\
\text { 2) Stimulation of critical thinking. } \\
\text { 3) Encouragement of self-learning. } \\
\text { 4) } \\
\text { Better understanding of course material. }\end{array}$ \\
\hline 4. & Sufficiency of Time & $\begin{array}{l}\text { T) The time provided for using multimedia } \\
\text { is sufficient. } \\
\text { 2) The learning process is more effective } \\
\text { and interactive. }\end{array}$ \\
\hline 5. & Evaluation & $\begin{array}{l}\text { 1) Exercise can help students to better } \\
\text { understand the material. } \\
\text { 2) Exercise can be used as a benchmark } \\
\text { for the students in understanding learn- } \\
\text { ing material, such as subnetting IP Ad- } \\
\text { dress. }\end{array}$ \\
\hline
\end{tabular}

\subsection{Multimedia Quiz Sheet}

This sheet is an evaluation sheet for testing and measure the achievement of the students after learning and practicing with this application. It contains questions about the material that has been provided in the learning multimedia. This sheet will be useful to see how well the utilization of this multimedia by the students.

\section{Method of Data Analysis}

The methods used for data analysis are as follows:

\subsection{Validity Analysis}

Analysis of the validity of the interactive web-based learning multimedia to the subject: installation of local network devices (LAN) uses the following formula:

\section{Validity Score $=\frac{\text { Number of score obtained }}{\text { highest score }} \times 100 \%$}

Criteria of validity score according to the Ministry of National Education of Indonesia (2008) as seen in Table 3 hereunder:
Table 3. Criteria of Validity Score

\begin{tabular}{|c|c|}
\hline Level of Achievement & Category \\
\hline$<51$ & Poor \\
\hline $51-70$ & Fair \\
\hline $71-90$ & Good \\
\hline $91-100$ & Very Good \\
\hline
\end{tabular}

\subsection{Practical Analysis}

Analysis of the practicality of the interactive web-based learning multimedia is applied by using the following formula:

Practicality Score $=\frac{\text { Number of score obtained }}{\text { highest score }} \times 100 \%$

After percentage of the practicality score is obtained, the researchers categorized such results in accordance with the scale developed by Purwanto (2009) as seen in table 4:

Table 4: Score of the Answers under Purwanto Scale

\begin{tabular}{|c|c|c|}
\hline No & Level of Achievement & Category \\
\hline 1 & $90 \%-100 \%$ & Very Good \\
\hline 2 & $80 \%-89 \%$ & Good \\
\hline 3 & $65 \%-79 \%$ & Fair \\
\hline 4 & $55 \%-64 \%$ & Poor \\
\hline 5 & $0-54 \%$ & Very Poor \\
\hline
\end{tabular}

\subsection{Effectiveness}

The aspect of effectiveness observed in the learning process using this multimedia is the study achievement reached by the student. The data is processed by using the formula developed by Trianto (2010);

Effectiveness Score $=\frac{\text { Number of score obtained }}{\text { highest score }} \times 100 \%$

Criteria of the Effectiveness Score:

Table 5: Criteria of Effectiveness Score

\begin{tabular}{|c|c|c|}
\hline No & Percentage & Criteria \\
\hline 1 & $76 \%-100 \%$ & Good \\
\hline 2 & $51 \%-75 \%$ & Fair \\
\hline 3 & $26 \%-50 \%$ & Poor \\
\hline 4 & $0 \%-25 \%$ & Very Poor \\
\hline
\end{tabular}

\section{Results}

\subsection{Validation of Product Design}

The validity test of this interactive web-based learning multimedia was conducted by way of making presentation before the Validators who thereafter filled in the validity sheet containing the assessment indicators as set out by the Ministry of National Education of Indonesia, with the results as shown in Table 6 below:

Table 6: Results of Validity Test

\begin{tabular}{|c|c|c|c|c|c|c|c|}
\hline \multirow{2}{*}{ No } & \multirow{2}{*}{$\begin{array}{l}\text { Aspect of Assess- } \\
\text { ment }\end{array}$} & \multicolumn{3}{|c|}{ Validators } & \multirow{2}{*}{ Amount } & \multirow{2}{*}{$\begin{array}{l}\text { Validity } \\
\text { Value }\end{array}$} & \multirow{2}{*}{ Criteria } \\
\hline & & 1 & 2 & 3 & & & \\
\hline 1 & $\begin{array}{l}\text { Substance of Mate- } \\
\text { rial }\end{array}$ & 11 & 13 & 11 & 35 & $89.74 \%$ & Good \\
\hline 2 & $\begin{array}{l}\text { Visual Communica- } \\
\text { tion Display }\end{array}$ & 19 & 19 & 19 & 38 & $100 \%$ & $\begin{array}{l}\text { Very } \\
\text { Good }\end{array}$ \\
\hline 3 & Instructional Design & 25 & 25 & 25 & 75 & $96.15 \%$ & $\begin{array}{l}\text { Very } \\
\text { Good }\end{array}$ \\
\hline 4 & $\begin{array}{l}\text { Utilization of Soft- } \\
\text { ware }\end{array}$ & 11 & 10 & 10 & 31 & $93.93 \%$ & $\begin{array}{l}\text { Very } \\
\text { Good }\end{array}$ \\
\hline \multicolumn{6}{|c|}{ Total } & $379.82 \%$ & \multirow{2}{*}{$\begin{array}{l}\text { Very } \\
\text { Good }\end{array}$} \\
\hline \multicolumn{6}{|c|}{ Average } & $94.96 \%$ & \\
\hline
\end{tabular}

In view of Table 6 above, the average value of validity test is $94.96 \%$ and categorized as very valid. This shows that the interactive web-based learning multimedia is "Very Good" in terms of 
feasibility of material substance, visual communication display, instructional design, and software utilization aspects.

\subsection{Practicality Test}

The results of testing of this product are represented by the practicality value of the learning multimedia as seen in Table 7 below:

Table 7: Results of Multimedia Practicality Test

\begin{tabular}{|c|c|c|c|c|}
\hline No & Variables of Practicality & Amount & $\begin{array}{l}\text { Practical Val- } \\
\text { ue }\end{array}$ & Criteria \\
\hline 1 & Students Interest & 736 & $87.61 \%$ & Good \\
\hline 2 & Process of Using & 421 & $87.70 \%$ & Good \\
\hline 3 & $\begin{array}{l}\text { Increase of Active Learn- } \\
\text { ers }\end{array}$ & 517 & $86.17 \%$ & Good \\
\hline 4 & Sufficiency of Time & 194 & $80.83 \%$ & Good \\
\hline 5 & Evaluation & 220 & $91.67 \%$ & Very Good \\
\hline \multicolumn{3}{|c|}{ Total } & $2610 \%$ & \multirow[b]{2}{*}{ Good } \\
\hline \multicolumn{3}{|c|}{ Average } & $87 \%$ & \\
\hline
\end{tabular}

In view of table 7 , the evaluation section is included in very practical category with percentage of $91.67 \%$, it shows that the students understand the material of how to process the subneting calculation in each existing IP class. As for the sections of students interest, process of using, increase of active learners and sufficiency of time, all of which show a practical category with the average practicality of $85.57 \%$.

\subsection{Effectiveness Test}

The effectiveness test is done by observing how many students get the learning outcomes which are above the Minimum Passing Criteria (76). The results being obtained are as in the following table.

Table 8: Results of Effectiveness Test

\begin{tabular}{|c|c|c|c|c|}
\hline No & Grade & Students & Category & $\begin{array}{c}\text { Percentage of } \\
\text { Passing }\end{array}$ \\
\hline 1 & 100 & 12 & Good & $80 \%$ \\
\hline 2 & 90 & 6 & Good & \\
\hline 3 & 80 & 6 & Good & \multirow{2}{*}{$20 \%$} \\
\hline 4 & 70 & 3 & Fair & \\
\hline 5 & 60 & 3 & Satisfactory & \\
\hline \multicolumn{2}{|c|}{ Total } & 30 & & \\
\hline
\end{tabular}

Source: Evaluation Result to the Students of Class XI of Computer Network Engineering Department on Using Multimedia

In view of table 8 above, $80 \%$ of the students managed to achieve the grade which are above Minimum Passing Criteria (76). 12 of the students successfully reached the highest grade, namely 100 . This achievement is in line with the results of practicality at evaluation section of the learning multimedia. Therefore, this learning multimedia is proven to be useful for the students of Computer Network Engineering in Padang, Indonesia.

\section{The Product}

\subsection{Main Pages}

\section{Interactive Learning Multimedia \\ Install Local Network Device}

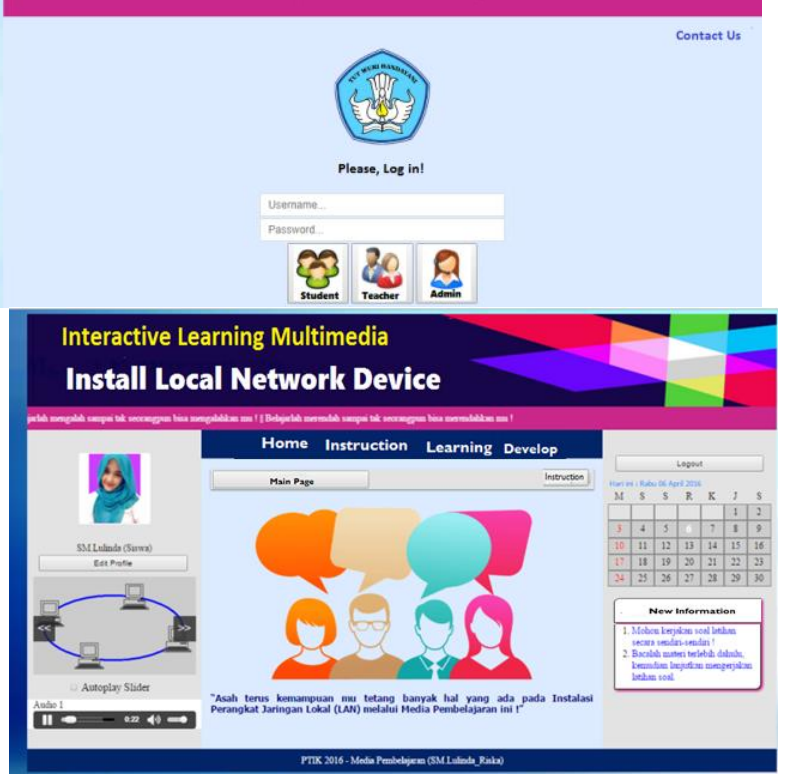

\subsection{Competency Standard - Basic Competence Page}

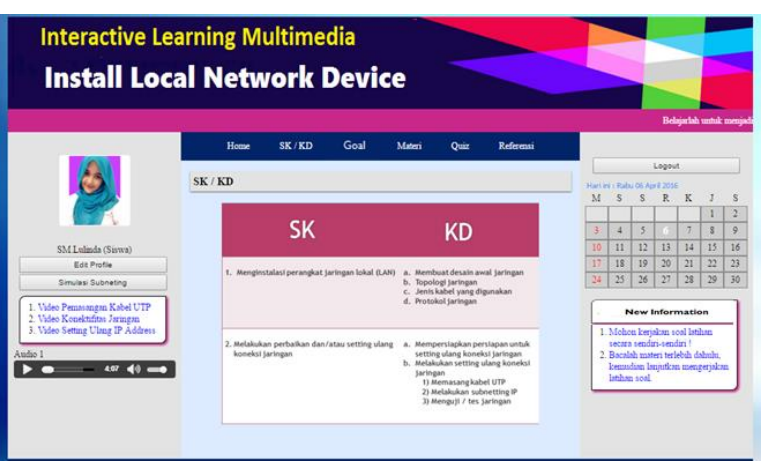

\subsection{Materials Pages (video \& pdf)}

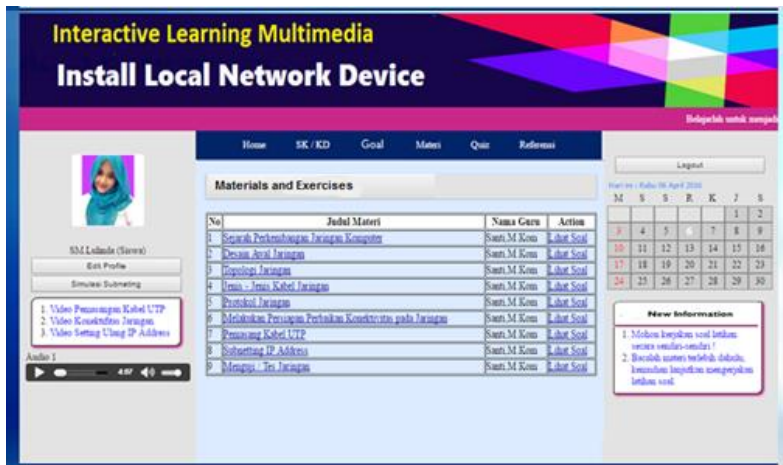




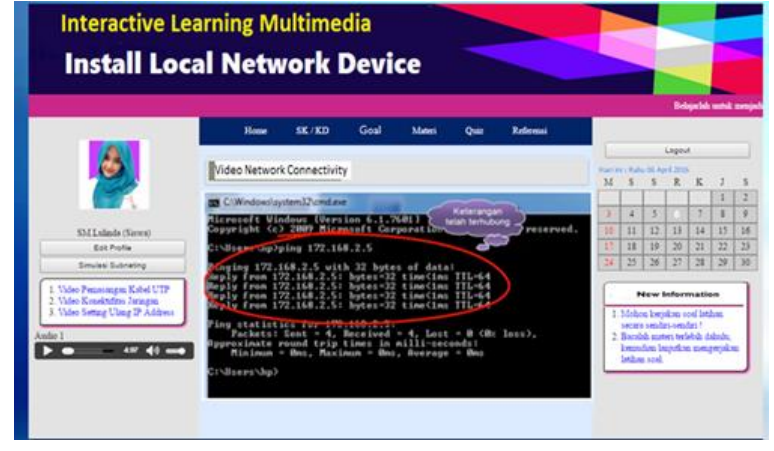

\subsection{Evaluation Page}

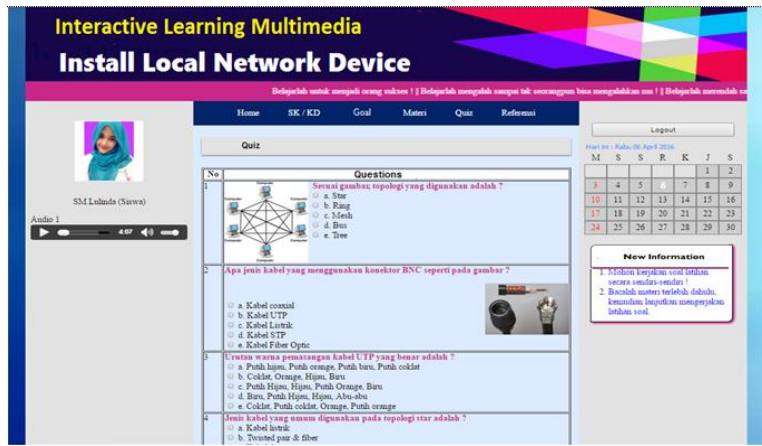

\subsection{Instruction Page}

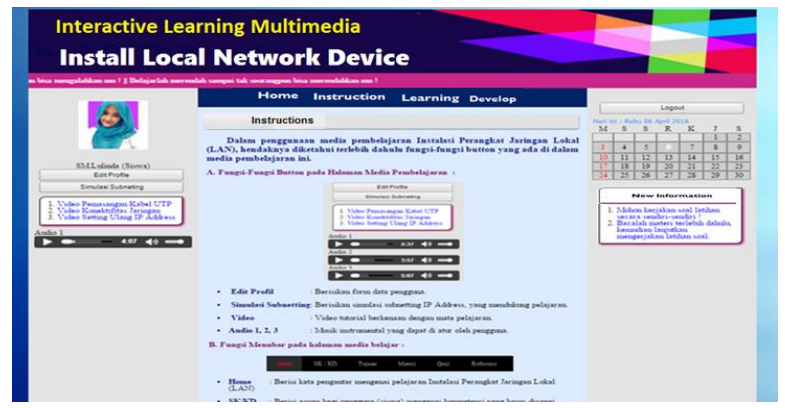

\section{Discussion}

This Learning Multimedia needs to be further developed at its database section for keeping the data on the grades already achieved by the students after taking the test and evaluation. This is particularly necessary in order to provide the students with an accessible database for them to conduct self-evaluation with regard to the progress of their knowledge upon the materials already given.

\section{Conclusion and Recommendation}

Based on the results of research already conducted, the Researchers conclude that they have successfully create a web-based learning multimedia which is interactive, valid, practical, and effective for the students to learn the subject: Installation of Local Area Network (LAN). The average score resulting from validity testing reached $94.96 \%$; which is a very valid category, the score of practicality testing reached $87 \%$ in average; which is categorized as practical, while the score of effectiveness testing successfully reached a good category, namely $87 \%$ in average.

\section{Conflict of Interest}

The authors declare no conflict of interest.

\section{Acknowledgments}

The authors acknowledge the support of Bung Hatta University, especially the lecturers in the Faculty of Teacher Training and Education who have validated the multimedia, and the students of Class XI, Department of Computer Engineering and Network at five Vocational High Schools in Padang City, Indonesia.

\section{References}

[1] Alsadhan, A. O., Alhomod, S., \& Shafi, M. M. (2014). Multimedia based E-learning: Design and integration of multimedia content in E-learning. International Journal of Emerging Technologies in Learning, 9(3), 26-30. https://doi.org/10.3991/ijet.v9i3.3308

[2] Cooper, R. G. (2005). Stage-Gate ${ }^{\circledR}$ New Product Development System : A Game Plan from Idea to Launch (pp. 1-12).

[3] Dikti, D. B.(2017) Panduan penyusunan perangkat pembelajaran \& bahan ajar 2017 (Guidelines for the preparation of learning tools \& teaching materials 2017).

[4] Kementerian Pendidikan Indonesia. (2008). Pengembangan Bahan Ajar (p. 23).

[5] Neo, T. K., Neo, M., Kwok, W. J., Tan, Y. J., Lai, C. H., \& Zarina, C. E. (2012). Mice 2.0: Designing multimedia content to foster active learning in a Malaysian classroom. Australasian Journal of Educational Technology, 28(5), 857-880.

[6] Purwanto. (2009). Prinsip-prinsip dan Teknik Evaluasi Pengajaran (principles and techniques of evaluation). Bandung: Remaja Rosdakarya.

[7] Rias, R. M., \& Zaman, H. B. (2011). Designing multimedia learning application with learning theories: A case study on a computer science subject with 2-D and 3-D animated versions. Asia-Pacific Forum on Science Learning \& Teaching, 12(2), 1-32. Retrieved from http://www.proxy.its.virginia.edu/login?url=http://search.ebscohost. com/login.aspx?direct $=$ true $\& d b=e h h \& A N=73182463 \&$ site=ehostlive

[8] Rufa, A. (2016). The Impact of Media A Perspective for Physical Therapists, 13(3).

[9] Rusman. (2011). Pembelajaran Berbasis Teknologi Informasi dan Komunikasi. Jakarta: Rajawali Press.

[10] Trianto. (2010). Model Pembelajaran Terpadu(Integrated learning model). Jakarta: Bumi Aksara.

[11] Winarno, S., Muthu, K. S., \& Ling, L. S. (2018). Impacts of mDPBL Approach towards Computer Networks Teaching and Learning Process. International Journal of Emerging Technologies $\begin{array}{llll}\text { in Learning } & \text { (iJET), } & \end{array}$ https://doi.org/10.3991/ijet.v13i03.7944 


\section{Annexure-A}

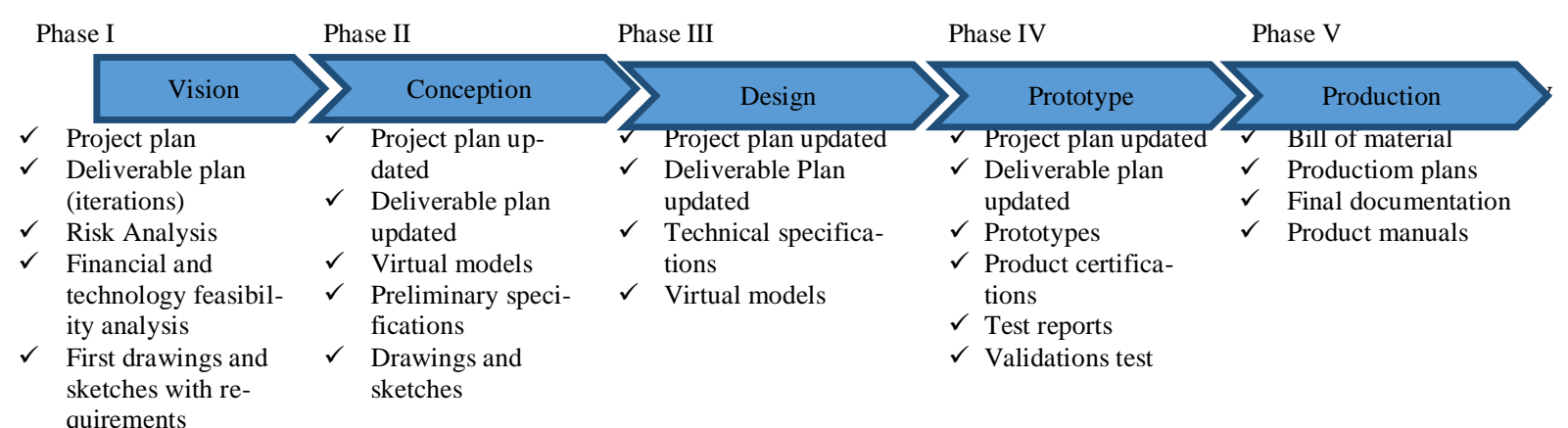

Source: Cooper (2005) Figure1. Product Development Phases and Main Deliverables 